\title{
ORGANIZATIONAL CULTURE, ORGANIZATIONAL CHANGE AND EMOTIONS: A QUALITATIVE STUDY
}

\author{
Roy K Smollan, Auckland University of Technology, Auckland, New Zealand \\ \& Janet G Sayers, Massey University, Albany, New Zealand \\ Published in 2009 in Journal of Change Management 9(4), 435-457.
}

\begin{abstract}
Change triggers emotions as employees experience the processes and outcomes of change, including cultural change. An organization's affective culture, which shapes the way emotions are experienced and expressed, plays a particularly important part during changes to the culture or to any other significant aspect of organizational life. This article contributes to the literature by illustrating the relationships between culture, change and emotions and presents the results of a qualitative study. We found that when participants' values were congruent with those of the organization they tended to react to change more positively. Cultural change provoked emotional reactions, often of an intense nature. When emotions were acknowledged and treated with respect, people became more engaged with the change.
\end{abstract}

Key words: organizational culture, organizational change, emotions, qualitative research

\section{Introduction}

Change is fundamentally about feelings; companies that want their workers to contribute with their heads and their hearts have to accept that emotions are central to the new management style...the most successful change programs reveal that large organizations connect with their people most directly through values - and that values, ultimately are about beliefs and feelings (Duck, 1993, p. 113).

There are a number of ways in which organizational culture, organizational change and emotions are related. Firstly, organizational culture is imbued with emotion and therefore cultural change is especially emotional. A change in culture can be the goal of management and but could occur indirectly as a result of strategic, tactical or operational changes. Secondly, an organization's affective culture influences how these emotions are experienced 
and expressed. Thirdly, there might be specific elements of a culture that an employee likes or dislikes and these influence emotional responses to any type of change. There is little literature that integrates employees' emotional responses to change with an analysis of their organizations' affective cultures. We aim to fill this gap by reporting on the findings of a qualitative study on changes experienced in multiple settings.

\section{Literature review}

\section{Cultural change and emotions}

Emotions are direct responses to events, issues, relationships and objects that are important to people (Lazarus, 1991; Frijda, 1988), whereas mood is longer lasting, more diffuse and not always linked to something specific (Isen, 2000; Weiss, 2002). Affect is a broad term including emotion, mood and disposition (Barsade and Gibson, 2007).

Organizational change has the potential to trigger positive and negative emotions and moods in the employee that depend on a range of factors. These include the perceived valence of the outcomes, the change processes that are used, the speed, timing and frequency of change, the nature of leadership and the employee's personality and emotional intelligence (Kiefer, 2005; Jordan, 2005, Wanberg and Banas, 2000; Smollan, 2006). The culture of the organization can also play an important role in both generating emotions during change and influencing their expression or suppression. The affective culture, in particular, will help or hinder employees' adjustment on an individual level.

Organizational culture is regarded as a set of assumptions, beliefs, values, customs, structures, norms, rules, traditions and artefacts (Schein, 2004). The term organizational climate is often used instead of culture, or in addition to it, and is the employee perception of the culture and a manifestation of it (Allen, 2003). The debate as to the similarities and differences between them, and the multiple theoretical perspectives on each (e.g. Allen, 2003; 
Payne, 2002; Denison, 1996), lie outside the scope of this article, and to simplify matters the term organizational culture will be used throughout.

More colloquially, culture is "how things are done around here” (Martin, 2002, p. 3) and it shapes the behaviour of its members in overt and covert ways. It has also been called a system of shared meanings (Pizer and Härtel, 2005) but how widely it is really shared is debatable (Martin, 2002). For example, sub-cultures exist in organizations (Allen, 2003; Ryan, 2005) which are often based on categories such as hierarchy, department, professional identity, ethnicity and gender, but may also be conceptualised as differing value systems. For example, Palthe and Kossek (2003) developed a typology of sub-cultures that are employeecentred, professional-centred, task-centred and innovation-centred. Employees’ responses to change are often coloured by their perceptions of, and engagement in, the sub-culture as well as in the broader organizational culture (Harris and Ogbonna, 1998; Morgan and Ogbonna, 2008). Sub-cultures may become counter-cultures or anti-cultures (Elsmore, 2001) and according to Armenakis, Harris and Mossholder (1993, p. 687), "these cultural memberships may polarize the beliefs, attitudes and intentions of members” through group discourses and undermine readiness for change.

Organizational culture is substantially about values (Kabanoff, Waldersee and Cohen, 1995; Ryan, 2005; Duck, 1993), which have been termed “embedded codes” (Branson, 2007, p. 382) - even if these might be contested. Values may evolve or be deliberately determined and articulated in mission statements and websites and included in induction and training sessions. In this way they are overt guides to behaviour but the messages and the mechanisms may be more subtle. They often contain emotional language, as the following corporate websites indicate:

The Virgin brand is built upon Richard Branson's core philosophy - if you keep your staff happy then your customers will be happy, and if you keep your customers happy then your shareholders will be happy (Virgin, 2008). 
At The Walt Disney Company, entertainment is about hope, aspiration and positive resolutions (Disney Corporation, 2008).

We have four core values (or passions) that are the 'glue' connecting Vodafone in every country around the globe. These are Passion for Customers, Passion for Our People, Passion for Results, and Passion for the World Around Us” (Vodafone New Zealand, 2008).

When Vodafone New Zealand acquired an internet service provider to enter a new market its work culture was reported in the press as being "energised". According to a senior manager the company's culture was "youthful, casual and fun” and that "it was important for workers to have energy and passion” to be competitive (Keown, 2006, p. C4).

Researchers have explored the emotions-culture nexus. Schein (1990, p. 111) indicates that "Culture is what a group learns over a period of time as that group solves its problems of survival in an external environment and its problems of internal integration”, and he emphasizes that "such learning is simultaneously a behavioral, cognitive, and an emotional process.” Focusing on the affective process he contends that one of the factors that contributes to the development of culture is the "emotional intensity of the actual historical experiences" organizational or group members have shared (Schein, 2004, p. 11). Beyer and Nino (2001) assert that culture both engenders emotions and provides for their expression in socially accepted ways and that culture acts as a 'glue' that binds people. According to van Maanen and Kunda (1989, p. 46), “Any attempt to manage culture is therefore also an attempt to manage emotions.” The role of emotion is emphasized somewhat idealistically by Bratton, Grint and Nelson (2005, p. 51), who claim that "The most critical function of corporate culture is to generate commitment and enthusiasm among followers by making them feel they are part of a 'family' and participants in a worthwhile venture.”

Organizational values are often reflected in the language that is used, and the language of culture in the context of change can be suffused with emotion. Martin (2002) explains how jargon both defines a culture and shapes it. For example, in researching mergers and 
acquisitions she noted that the informal use of terms such as 'shark', 'ambush', 'stud', 'cupid', 'rape' and 'afterglow' reflect themes of sex and violence and that these "metaphors tap the emotional aspects of life in particular kinds of organizations and industries, alluding to emotions that may not be socially acceptable to express more directly” (p. 80).

If, as Branson (2007, p. 377) claims, "values alignment is the bedrock of successful organizational change”, this process needs to be carefully managed but nevertheless cannot always work. A person's sense of identity is partly determined by his or her values, which can mesh or clash with organizational values (Ashforth and Mael, 1989; Pepper and Larson, 2006). As Ryan (2005, p. 432) puts it, culture "represents the often unwritten sense of identity, feeling part of the organization. It provides a 'glue' and understanding in that it can help individual members make sense of events and change activities.”

According to Carr (2001, p. 429), "the processes involved in the relationship between employee and organization are deep-seated, largely unconscious, intimately connected to the development of identity; and have emotional content.” He suggests that change 'dislodges' identity and leads to anxiety and grieving. Van Knippenberg, van Knippenberg, Monden and de Lima (2009) reported from a study of a merger that members of the dominant company felt a much stronger form of organizational identification than the members of the other company. Similarly, Larson and Pepper (2006) found in a takeover that members of the acquired company resisted the values of the acquiring company, as a result of what they termed ‘identity tensions'. Van Dijk and van Dick (2009) found that change can undermine an employee's identity, particularly in terms of social status, while resistance to change undermines a change leader's identity as a person with power. It should also be emphasized that in addition to its cognitive and behavioural components, resistance to change is also affective (Piderit, 2000; Szabla, 2007), but the role of affect is frequently overlooked or 
discounted as irrational (Domagalski, 1999). In the context of cultural change the emotional elements, wrapped as they are in values and identity, are particularly salient.

A number of other examples provide evidence of the dissatisfaction and alienation that can be experienced by employees when culture changes. Eight years of structural change at GE, according to Huy (2001, p. 619), "left remaining employees reeling from cultural shock and its managers exhausted.” Kavanagh and Ashkanasy (2006) found that when values were threatened by change in the tertiary education sector, employees responded with defensiveness, shock and lower levels of trust. Having conducted in-depth studies of two privatised organizations Elsmore (2001) concluded that changing culture on a large scale is a long term endeavour and causes pain and anguish, particularly when the change is legislated in a top-down fashion. Brooks and Harfield (2000) report on a culture change programme in a local government authority from a civil service mentality to one of 'public management' where the user pays for a service. The cultural change programme, known as 'Giving Value Being Valued', was considered inequitable since the 'Being Valued' component fell short of the effort expended by staff in 'Giving Value', and evoked negative emotions. At HewlettPackard strategy, structure and culture all changed with a new CEO (Forster, 2006). The family-culture of previous years gave way to one more focussed on the individual and profitsharing was replaced by individual performance measures. A number of disaffected staff resigned. Schein (2004, p. 309) points out that new leaders, who are often brought in specifically to change the culture, need to deal with emotional reactions:

The infusion of outsiders inevitably brings various cultural assumptions into conflict with each other, raising discomfort and anxiety levels. Leaders who use this change strategy therefore have to figure out how to manage the high levels of anxiety and conflict they have wittingly or unwittingly unleashed.

Ryan (2005, p. 433) documents reactions in a company which moved from a culture that "always claimed to value people" to one perceived by an employee where "the shareholders 
are more important than the employees.” Another company, the communication giant, Cisco, had a culture of innovation but also one that was termed "brutally competitive", and when results declined it maintained the focus on goals, but, together with other changes, also demanded forms of collaboration that subtly altered the culture:

Everyone hated the new way at first...Executives didn't like sharing resources; joint strategysetting and decision-making was cumbersome....'The first two years were very painful' admits [CEO] Chambers. Some of the most successful people left...Others were asked to leave (Kirkland, 2007, p. 38).

\section{Affective culture}

Given that change, especially cultural change, can ignite emotional reactions, the affective culture of the organization is important in signalling to staff how emotions are to be experienced, expressed and regulated (Alvesson, 2002). The emotional aspects of the organization's culture have been termed affective culture (Barsade and Gibson, 2007), emotional culture (Zembylas, 2006) and affective climate (Tse, Dasborough and Ashkanasy, 2008). Beyer and Nino (2001) contend that culture can shape emotions by encouraging the experience of emotions, providing ways to express them and managing anxiety. A healthy organizational culture, according to Pizer and Härtel (2005), is one where emotional expressiveness is encouraged and value is placed on the emotional elements of work. Ashkanasy and Daus (2002) provide a set of guidelines for emotionally healthy organizations that includes selecting employees for emotional sensitivity, training them in emotional intelligence and the healthy expression of emotion, creating a positive and friendly emotional climate, and if need be, changing the culture. Conversely, organizational culture can be seen as a mechanism for the cynical manipulation of the employees' emotions, which need to be controlled for the benefit of the organization (Fineman, 2001; Zembylas, 2006). 
A number of inter-locking constructs highlight the potentially affective nature of organizational culture: emotional labour, perceived organizational support, organizational emotional intelligence and systemic justice.

Firstly, the extensive literature on emotional labour has indicated how the experience, display and suppression of emotions at work has been determined by a host of societal, organizational, professional and individual factors (e.g. Hochschild, 1983; Rafaeli and Sutton, 1991; Mann, 1999; Alvesson, 2002; Bolton, 2005; Turnbull, 1999). The affective culture of an organization can result in emotions being 'captured', 'harnessed', 'managed', 'controlled', 'sanitised', 'codified' and 'commodified' by organizations for their own ends, and often at the expense of the employee (Kunda and van Maanen, 1999; Sturdy and Fineman, 2001; Fineman, 2000, 2001, 2003, 2005, 2008; Zembylas, 2006). Emotions become 'cultural prerogatives' (Fineman, 2008) when some are deemed appropriate for display while others must be contained (Lewis, 2000). Callahan (2002) found in a qualitative study that employees were expected to hide their emotions and that the emergence of new and healthier norms was being stymied by an unresponsive organizational culture. Expectations of emotional expression and control become cultural norms that are not only imposed and monitored by managers but also can be policed, or at least influenced, by peers (Haman and Putnam, 2008; Zembylas, 2006). Alternatively, organizational culture can embrace emotional experience as natural and its expression as acceptable (within certain boundaries). The determination of companies like Disneyland to control employee emotions (van Maanen and Kunda, 1989) can be contrasted with The Body Shop where emotional expression is considered legitimate (Martin, Knopoff and Beckman, 1998), or at least it was under its original owners. Clarke (2006) has also documented the impact of organizational culture and professional identity in healthcare organizations which encourage reflection on, discussion of, and support for the emotional aspects of work. 
Emotional labour can be required to lead and implement change since those entrusted with these tasks need to inject the appropriate type of emotion into selling the change (Fox and Amichai-Hamburger, 2001). Change initiatives can also lead to emotional labour in change managers (those who implement change) and change recipients. Bryant and Wolfram Cox (2006) found a number of their respondents felt the need to hide their emotions about organizational change since their expression was construed as an unwelcome form of resistance. Turnbull (2002) studied the ways individuals responded to an organization's attempts to deliberately change its culture to one of trust, openness, innovation and loyalty, in workshops laden with emotional appeals. She found that managers, the subjects of her study, experienced both cognitive and affective reactions, but often in unintended ways, with mistrust, anger and embarrassment often eventuating from awkward situations. They reported the need to hide their feelings and in many cases pretended to comply with the changes.

Secondly, the concept of perceived organizational support has been applied to a variety of organizational contexts, including change, as Naumann, Bennettt, Bies and Martin (1998) demonstrated. It can refer to how employees perceive the support of individual managers (Masterson, Lewis, Goldman and Taylor, 2000), particularly when they encounter difficulties, but is usually more broadly related to perceptions of organizational systems and culture. Support may be of a practical nature but also includes the notion that emotions need to be acknowledged and treated with sensitivity. Eisenberger, Huntington, Hutchison and Sowa (1986, p. 500) maintain that "employees in an organization form global beliefs concerning the extent to which the organization values their contributions and cares about their well-being” and that this leads to greater organizational commitment, views corroborated in empirical studies (e.g. Currie and Dollery, 2007; Loi, Hang-yue and Foley, 2006). Supportive organizations provide employee assistance programmes (Alker and McHugh, 2000) and outplacement programmes, such as psychological and career counselling (Rudisill 
and Edwards, 2002), help with constructing curricula vitae, methods of job search and interviewing skills. However, there is little research about the emotional effects of perceived organizational support during periods of change.

Thirdly, organizational emotional intelligence (EI) is a development of the individuallevel construct of EI, the ability of people to understand their own emotions and those of others, and respond appropriately (Mayer and Salovey, 1997). Huy (1999) asserts that organizations should develop the capability of responding to emotions and that this helps to facilitate organizational change. Clarke's (2006) qualitative study, referred to earlier, identifies organizations with this emotional capability. In the only empirical quantitative study to date, Menges and Bruch (2008) demonstrated that employees perceived that organizational EI improved performance in a number of ways, including innovative capability. Group-level EI has a stronger conceptual and empirical base (Druskat and Pescolido, 2005; Jordan, Ashkanasy, Härtel and Hooper, 2002) but has not been related to change. Neither has group EI been specifically researched as a feature of sub-cultures.

Fourthly, perceptions of justice/injustice, particularly when it is systemic (Sheppard, Lewicki and Minton, 1992; Beugré and Baron, 2001), can create organizational cultures of contrasting emotional natures from the warm to the toxic (Frost, 2004). As a construct, systemic justice is an amalgam of other types of justice, distributive, procedural and informational and interpersonal (Colquitt, 2001), all of which can produce strong emotional reactions to organizational events, including change (Barclay, Skarlicki and Pugh, 2005). Respondents in the study conducted by Harlos and Pinder (2000, p. 261) reported on companies that were rife with humiliation, degradation and intimidation, resulting in employees feeling “anger, sadness, outrage, grief, shame and hate.” Loi et al. (2006) found that perceptions of distributive and procedural fairness were enhanced by perceptions of 
perceived organizational support and contributed to affective commitment. However, the impact of systemic justice on organizational change has not been given much attention.

Taken together the four constructs of emotional labour, perceived organizational support, organizational EI and systemic justice, indicate that the emotional culture of an organization influences employee reactions to everyday events - and the experience of change. Empirical research in to organizational change has analyzed it in terms of two or more of these constructs in the same study (e.g. Naumann et al., 1998; Masterson et al., 2000; Loi et al,. 2006).

\section{Affective responses to existing culture when change occurs}

Emotional responses to specific elements of the existing culture of an organization can influence how an individual responds to a strategic, cultural or operational change. For example, if an employee dislikes the competitive aspect of an organizational culture he/she may be predisposed to feel negatively about the introduction of an individual bonus system. Alternatively, if an employee is pleased with the existing participative culture there is a likelihood that he/she will feel comfortable in disagreeing with the change. However, this does not guarantee that the actual change will produce a positive emotional response. Studies of person-organization fit show that when individual values are congruent with organizational values they produce conscientiousness, organizational citizenship behaviours (Goodman and Svyantek, 1999), less staff turnover and higher job satisfaction and organizational commitment (Amos and Weathington, 2008). By implication this could extend to positive attitudes to change. Affective commitment to change occurs when employees want to remain in the organization and supports its change efforts (Herscovitch and Meyer, 2002; Cunningham, 2006) but there appears to be little research into the relationship between affective commitment to a culture and affective commitment to a change. 
To summarise our intent, this article is concerned with three related research questions: What emotions are triggered when an organization's culture changes? How does the emotional culture of an organization influence the ways in which emotions are experienced and expressed when any type of change occurs? How do affective responses to existing culture influence affective responses to any type of change? We sought to answer these questions by interviewing people on their experiences of organizational change and the role culture played, either as a target of change or as a backdrop to it.

\section{Methodology}

For this study we have adopted a qualitative/social constructionist approach because it provides a useful way of understanding the three main constructs of organizational culture, emotions and change, all of which have been subjected to social constructionist treatments in the literature. "A general assumption of social constructionism is that knowledge is not disinterested, apolitical, and exclusive of affective and embodied aspects of human experience, but is in some sense ideological, political and permeated with values” (Schwandt, 2003, p. 307).

One of the major dimensions of organizational culture is a set of values (Schein, 1990; Martin, 2002) which are moulded by both intra- and inter-organizational forces (Strandgard Pedersen and Dobbin, 2006). Organizational cultures can be shaped by explicit management intervention but are also influenced by multiple employee (and managerial) discourses and sub-cultures so that there is often a divide between espoused and perceived values (Kabanoff et al., 1995). The social processes that enact the values "endow them with meaning” (Rosen, 1991, p. 6), and, as Allen (2003) puts it, organizational actors create, but are also constrained by, organizational meaning.

The social constructionist perspective of emotions takes the view that emotions are phenomena that are culturally mediated (Antonacopoulou and Gabriel, 2001) and developed 
through interaction in social relationships. Cultural factors influence not merely the experience of specific emotions (such as shame, anger or pride) but also influence how appropriate their display is. Commenting on this approach Callahan and McCollum (2002, p. 14) indicate that "emotions are created or constructed as part of a common sensemaking process in social structures" and that "social constructionism knits together the personal and the social.” Social constructionism underlies much of the literature on emotional labour (e.g. Mann, 1999; Bolton; 2005; Fineman, 2008). Zembylas (2006) notes that the feeling and display rules that operate in organizations are both contributors to, and outcomes of, organizational culture.

Change has also been the subject of social constructionist approaches. The way in which change is framed by various organizational actors (for example, as an exciting opportunity or a response to problems) can stimulate discourses about change (Bean and Hamilton, 2006; Mills, 2000; Ford, Ford and McNamara, 2002) that may or may not result in shared understandings. Resistance to change may be seen as culturally acceptable and negotiable - or as unacceptable as a barrier to be 'dealt with' or 'managed' (Dent and Goldberg, 1999; van Dijk and van Dick, 2009). The emotions that people experience, express or suppress during organizational change, are shaped by social relationships inside and outside the organization (Bryant and Wolfram Cox, 2006).

To explore the interaction between organizational culture, change and emotions we interviewed 24 people in Auckland, New Zealand, in 2006 and 2007. There were 11 women and 13 men, 16 European, two Maori, three Asian and three of Pacific Island background. The participants came from a variety of industries, organizations, functional departments and hierarchical levels. They had experienced a wide range of changes including mergers, restructuring, redundancy, relocations, new systems and job redesign. Participants were sourced through management consultants who knew them so that we had no previous 
relationship with them. The interview was part of a larger project on emotions and organizational change and one question participants were specifically asked was, How did the culture of the organization impact on your emotional responses to the change? Some commented on how the change had affected other employees and some also referred to the influence of organizational culture elsewhere in the interview.

Part of the social construction of knowledge rests on how researchers select and interpret interviewee comments. We drew up a table of the 24 participants and noted key issues and quotes from the transcripts that deal with organizational culture. We particularly looked for the emotional ramifications of changes to the culture, the influence of the affective culture, and for how positive and negative views of the existing culture impacted on their emotional reactions to any of the changes they were discussing. We also examined whether emotional support been provided by leaders and managers of change and whether this was evidence of cultural norms. The analysis of the findings is therefore our reconstruction (Schwandt, 1998) of the dynamics of culture, emotions and organizational change.

\section{Findings}

For some participants organizational culture was one of the contents or targets of change, for others it was merely context, and its salience varied considerably. Comments were made about the types of culture, how they changed and what the emotional consequences were for the interviewees and their colleagues. Several participants specifically commented on the place of emotion in their organizational cultures and how the changes had influenced their own affective experiences.

\section{Cultural change and emotions}

Participants experienced both and positive and negative emotional reactions to changes in 
organizational culture but the latter tended to dominate. $\mathrm{P}$ was very scathing about the government department that took over her organization. She referred to a "cultural takeover" where her organization's culture "died” and which had "a huge demoralizing effect on the team”. She commented that whereas previously

We were able to take calculated risks... That stuff didn't survive and wouldn't survive in the Ministry. Bureaucracies can’t help themselves, they impose processes that completely kill any degree of risk taking...We certainly felt under-valued and demoralised....There was a real culture of stamping on any of the sort of features of our culture in the past. It was...big brother stomping on little brother. We used to be able to give people some delegation around managing contracts and signing off funding... They took that away and so that had a huge affect on people's ability to be quite passionate about their roles.

A change in values often negatively undermines people's sense of identity. This was particularly evident in managers who lost status. A few months after her company was acquired, $\mathrm{H}$ was replaced as general manager by a man appointed by the new owners. The predominantly male management team quickly introduced a very different type of culture, which, together with the diminution of her role, resulted in anxiety, anger and frustration, and led her to negotiate an exit. One change in culture was the practice of new managers emailing her from the next door offices; another was a stronger focus on sales and profits and less on people. Gender issues also surfaced:

It was all about Friday night drinks... and you could share a drink with the boys on a Friday...the office girls would join in, and I would occasionally come in...but the girls were then excluded from the rest of the evening's proceedings...I would never be invited...they would usually go to the rugby, or go to the races or something like that.

A, who was a senior manager, commented that his organization had moved "from a participative culture to a directive culture" and that he "felt disenfranchised...therefore that had a major impact on my sense of belonging to the organisation.” He also spoke of having "a sense of grief” and feeling "disenchanted" as a result of the change. On a more positive note, 
C was transferred to a new company that had bought his division. He appreciated moving from what he termed a "gloomy atmosphere" to an organisation that was "more like a family business”. Different stakeholders will view the same cultural change through different lenses. $\mathrm{R}$ was brought in as a senior human resources manager to effect a number of structural, operational and cultural changes in a professional services firm that she described as archaic, conservative and traditional. Whereas the previous culture was one of status, $\mathrm{R}$ noted that in the new era, "We were trying to build a culture of integrating and sharing and working as a team”, an aim that was strongly supported by the chief executive. She found that many staff, including those who had been partners, struggled to adapt to the new practices, and the new culture that underpinned them, particularly for those who believed that they had lost status, identity, authority, benefits and pay. Others thrived in the new regime.

When values change, as $\mathrm{R}$ found, people often resist the change, at least initially. Another senior manager, G, acknowledged that whereas previously the company had provided a culture of support it became necessary to supplement it with a performance culture. He believed that this had been well managed because of the strong human relations element in the existing culture. $\mathrm{W}$ was the head of human resources of a company that took over another. The employee of the latter, he claimed, had been “deeply scarred” by their previous owners. When changes were made, some of which reflected a change in values, existing levels of animosity and suspicion proved to be a significant challenge. Even though $\mathrm{W}$ believed that the culture of the acquiring company was considerably more positive he thought that it would take a long time for the changes to take root amongst employees in the new division.

\section{Affective culture}


The need to control emotions is a key element of the construct of emotional labour and was a challenge a number of participants had to face. While some of the drivers were personal others lay in the organizational culture. $\mathrm{X}$, a first level employee, believed that if people voiced dissatisfaction with changes in his organization they "became a target". For a few of the participants emotion management was considered part of the role of the 'professional' image of the manager and some indicated that their organizational culture played a part. W felt that emotional expression was a facet of senior management interaction but he admitted that he was careful not reveal his emotions to lower level staff. A, a male manager in an engineering company, claimed that "people in this profession are notorious for not getting in touch with their emotions" and that his organization was no different. He also advanced the view that his organization had "a very strong professional managerial culture” and this influenced the way he controlled his emotions when the culture became less participative. Two female managers, $\mathrm{H}$ and $\mathrm{L}$, observed that in male-dominated environments they had to be particularly careful in controlling their emotions. $\mathrm{L}$ found it hard to deal with sexist attitudes, including her boss’s remark "may the best man win” (when referring to two women who were made to compete for one position in a structural change). She believed that his comment was typical of a firm dominated by men and observed that the culture of the organization was:

very male, engineering male, technical, not emotional on the outside...very stiff upper lip environment... as a woman operating in a senior role...I don’t think along those gender lines...but I was expected to toe that line always, and it was confusing too because...sometimes they expected you to be girly and other times they didn’t, but you couldn’t really tell when was the right time.

When she cried on one occasion she was told she was a "bit soft" and she vowed not to let it happen again because of the macho culture. She did, however, observe that she had worked for the company for over 13 years and that over time sexist attitudes and the emotionally neutral type of culture had changed markedly. Another female employee, D, “wanted to sit 
there and howl” when advised of her redundancy, but laughingly remarked that, being "English, stiff upper lip, you try not to show your emotions.”

Perceived organizational support was evident in the comments of some participants but noticeably absent in others. A number commented that their direct supervisors, and sometimes those more senior, were aware of their emotional reactions and provided psychological support. This afforded them a degree of comfort. Some interviewees who were leaders and managers of change were proud that their organizations had provided support to staff during difficult periods of change. Those who managed redundancies said they had put in considerable effort to give tangible help, such as help with writing curricula vitae and approaching neighbouring firms to hire their staff, and psychological support, both personally and through employee assistance programmes. G spoke of the company’s development and articulation of values where people are important: "Our frame of reference was if that's happening to me what would I want to happen?” The way the firm managed the redundancies was consistent with these values. In his words, organizational culture was "the glue that made it doable".

Several participants reported that negative cultures were characterized by the absence of support, which led to a host of deleterious consequences. D was surprised to find that her organization, which she had previously found to have a very supportive culture, suddenly found it acceptable to make her redundant with immediate effect, and with seemingly little understanding of the pain and embarrassment that this would cause her. B found no understanding of the way in which she was "drowning”, little concern for people shown by those at senior management level (but more at lower managerial levels), lack of trust and instances of injustice.

Organizational emotional intelligence (EI) was not easy to uncover, but the remarks of $\mathrm{L}$ and $\mathrm{A}$ are indicative of cultures where authentic emotional expression was frowned on. The 
impact of the perceived EI of the participants' managers or more senior staff generated emotion in some of the participants but the interviews did not reveal the extent to which this reflected organizational EI as a facet of culture.

Issues of justice and injustice can impact on the affective culture of an organization and were recorded elsewhere in the interviews. P was highly critical of the unfairness of many aspects of the changes and saddened at how dysfunctional the new culture had become. B left because she found the culture unacceptable, partly due to many instances of injustice meted out to employees as well as to herself. When participants were in the role of change leaders, however, they tended to the view that their organizations handled change in very fair ways, and that this was indicative of their organization's values. However, for most respondents it could not be gauged whether injustice was systemic in any of the organizations, and therefore a cultural facet, or whether it led to widespread perceptions of a hostile emotional climate, particularly when charge occurred.

\section{Affective responses to existing culture}

Some employees did not like aspects of their existing cultures and when change took place it confirmed elements they did not like. J said that his organization had a culture of "bowing down" to customers to reduce prices, regardless of the financial cost to the company and the emotional cost to the employees. When an operational change took place in an effort to retain the business of a major client, he resented how this impacted on him and his staff, since they had to compromise quality standards and spend long hours on working out ways to cut prices.

B commented that one department of a large organization had a "horribly dysfunctional” culture, but this seemed to mirror her views of the organization as a whole. She had negative emotional responses to the culture of her organization, which manifested itself in various ways, including autocratically led changes and lack of concern for staff when 
change was implemented. “I hadn’t been comfortable with the culture really since I'd been working there. I didn't like the culture at all. That was why I was leaving really. It was because of the culture.”

Other than B, only $\mathrm{L}$ referred to sub-cultures. As a human resources manager she spoke of the divide between her departmental culture from the dominant engineering culture: “The culture was such that if you weren't an engineer then you were an overhead, therefore you cost them money, therefore you take up as little time as possible, but you'd better achieve because they are paying you.” This also became a factor when change was being designed.

Over time, when the culture changed to a more inclusive one her level of comfort increased markedly.

\section{Discussion}

As we have shown in the findings, a number of themes were identified that signal the prevalence of the emotional ramifications of cultural change, and of the influence of an organization's affective culture on any type of change. We also demonstrated the interrelatedness of several of the constructs used in this study. For example, negative emotional reactions were reported when participants thought that the processes and outcomes of change were unfair, where organizational support was not provided and when they felt unsafe in voicing their dissatisfaction with a change. The study therefore confirms the view of many theorists that it is important to acknowledge the role culture plays in facilitating or impeding organizational change, and reinforces the message that emotion accompanies many aspect of change and must be handled sensitively.

\section{Cultural change}


It was evident that some values of an organization can play a constructive role in facilitating change in other values, such as G's remark that his company's culture of concern for staff was the 'glue' that made adding a performance element to the culture possible. Glue is the same word used by Ryan (2005) and Beyer and Nino (2001) and is also found in the section on values in the Vodafone New Zealand website (Vodafone New Zealand, 2008). Getting staff to buy into a new culture through values alignment might be the key to successful change, as Branson (2007) indicates, but is not easy to achieve. A number of participants in the current study did not like the new values that were imposed on them and resisted the change on affective and other levels. This resistance was partly due to their identities being 'dislodged’ (Carr, 1999), particularly when their organizations were taken over by others. Previous studies of mergers and acquisitions have shown how an individual's construction of his or her own identity is interconnected with a corporate identity and when change occurs in the latter it can fragment the former (van Knippenberg et al., 2006; Pepper and Larson, 2006; van Dijk and van Dick, 2009). Some of the affective resistance was due to new cultures that appeared to be less participative than those previously experienced. Exclusion from decisionmaking has been seen as a significant barrier to organizational change by previous researchers (e.g. Kotter and Schlesinger, 1979; Lines, 2004). This may be especially damaging to the identities of managers, such as A and P, who previously had participated in decisions, the partners in R's professional services firm and $\mathrm{H}$, who had previously enjoyed considerable authority as general manager. Identity can also be viewed as a group-based phenomenon and van Dijk and van Dick (2009, p. 146) "suggest that employees who identify with a salient social group that is negatively impacted by the change process are resisting a loss of status for that ingroup as a whole.”

\section{Affective culture}


An overall analysis of participants' comments revealed many types of affective culture. It was evident that those leading change tended to view their organizations as having a positive affective culture, but those managing change or simply being recipients of it, had more varied perceptions. Four theoretical constructs were engaged as reflective of the affective culture of an organization and were found in varying degrees to be relevant to the participants' experience of change. Controlling one's emotions, a prominent feature of emotional labour, was seen as necessary for a number of participants. For those who were recipients it was considered to be a survival mechanism and some of the comments were similar to those in the studies conducted by Turnbull (2002) and Bryant and Wolfram Cox (2006). The affective culture of an organization can thus exert subtle or more direct pressure on employees to conform to norms. Female participants in particular felt it unbecoming to cry in front of male bosses or colleagues. Researchers have commented on how organizational norms of emotion management have been constructed by men to marginalize women (e.g. Putnam and Mumby, 1992; Guy and Newman, 2004).

Several participants in the current study tasked with implementing change reported the need to hide their own emotions from their subordinates because this was 'professional'. Researchers have pointed out that professional identity is a social construction in that managers are expected to act in approved ways (Roberts, 2005; Fournier, 1999; Fineman, 2003). What often goes unsaid in organizations is the need to control 'inappropriate' emotions (Lewis, 2000).

Perceived organizational support has been theorized to create a warm emotional climate (Eisenberger et al., 1986) and in the current study participants who experienced support felt some comfort. People who are struggling with either the outcomes or the processes of change need their feelings to be validated rather than being ignored, and resent being told to 'harden up'. According to Jordan (2005) managers who are high in EI are able to 
leverage this understanding of their subordinates and facilitate adaptation to change, and this was appreciated by the participants in the current study. Where organizations are able to cultivate these insights and abilities in a significant number of managers they can lay claim to providing adequate organization-wide support and EI. Reference to fairness by the participants was directed more at elements of the change itself and could not be construed as evidence of the construct of systemic justice, which is a perception that fairness abounds in most aspects of an organization’s systems and actions (Beugré and Baron, 2001).

\section{Affective reactions to existing culture}

Culture, according to Bratton et al. (2005) is supposed to generate positive emotions in employees. Participants in the current study had positive and negative perceptions of their organizations' culture and congruent emotional reactions. As Schein (1990) points out, perceptions of a culture influence emotional reactions and behaviour. These played a role in how participants made sense of changes. However, organizational culture is a multi-faceted concept and some values and practices may engage an employee while others may have the opposite effect. Commitment and job satisfaction have been shown to increase when employees' values are in harmony with those of the organization (Amos and Weathington, 2008) and higher staff turnover when they are not (Goodman and Svyantek, 1999),

\section{Limitation and avenues for further research}

We now move to suggesting how further research could develop these exploratory findings and outlining some implications of this study. In the present research we investigated individuals' perceptions of how culture affected their emotions during change events. This

study, therefore, uses ideographic perceptions of organizational culture from individual subjects influenced by change. However, given that our focus has been on emotions in 
relation to change events, this approach is justified in our opinion.

Methodological debates about researching organizational culture are as heated as they are in other areas of organizational behaviour (e.g. Rosen, 1991; Martin, 2002). The wider project covered many causes of emotional responses to change and therefore did not delve into culture in as much depth as a more narrowly targeted study would. Quantitative studies within organizations and across national boundaries may give a much more detailed picture of organizational culture, and its affective elements, and of the influences of nationality, ethnicity and gender. Ethnographic accounts could provide a deep and rich vein of material that is peculiar to an organization, such as those provided by van Maanen and Kunda (1989) Martin et al. (1998) and Elsmore (2001). Further research may have the capacity to more completely capture the many variables at play when considering emotional reactions to change events, such as emotional labour, perceived organizational support, organizational EI, systemic justice, sub-cultural issues, professional norms and gender factors. In addition, the roles of leaders in creating, sustaining and changing culture, and the degree to which they infuse culture with emotion needs deeper exploration.

A further consideration is that participants in this study were all from New Zealand organizations. The influence of wider national and ethnic influences on the culture of the organizations they commented on may have played a part in their reactions, and these might differ from factors in other countries. According to Vandenberghe (1999, p. 197), “any corporate culture partly reflects the values of the country in which the organization is located.” Consequently, studies in other countries, and cross-country comparisons, are recommended.

One of the implications of this study for practitioners is that organizational culture must be taken into account as a potentially relevant factor in the ways in which people respond to change. Since culture has emotive elements and change is frequently emotional, it 
is important for managers and consultants to be aware of the culture of the organization and what the consequences are when it changes. Surveys of change readiness, such as those advocated by Holt, Armenakis, Field and Harris, (2007), could be broadened to include aspects of organizational culture, affective culture, perceived organizational support, EI and fairness. These elements also need to be analysed at the level of work groups and other subcultures (Tse et al., 2008; Morgan and Ogbonna, 2008). As Martin (2002) herself notes, people seldom agree on more than a few aspects of culture and the rest are beset by paradox, inconsistency, contradiction and ambiguity. Training people in EI, which should produce higher levels of organizational emotional capability (Huy, 1999), has been recommended by a number of researchers (e.g. Jordan, 2005; Ashkanasy and Daus, 2002; Druskat and Wolf, 2001) and courses have been offered by many providers. Empirical studies on its effectiveness are in their infancy (see McEnrue, Groves and Shen, 2009; Ciarrochi and Mayer, 2007) and also need to be done in the context of organizational culture and change.

\section{Conclusion}

Organizational change has the capacity to alter the culture, whether deliberately or not, and thereby influence people's emotional reactions. Conversely, the culture affects the way in which staff respond to the change on an emotional level. Arguments have been advanced by researchers that organizational culture, change and emotions are socially constructed. Many have criticized the cynical way in which all these elements have been deliberately manipulated to control people and harness them to the organizational machine (Sturdy and Fineman, 2001; Zembylas, 2006). Yet if employee engagement is to be authentic organizations need to create cultures sufficiently strong to embrace change without altering their fundamental ethos and to develop an acceptance that emotions are a natural part of organizational culture and organizational change. 
This study has contributed to the literature by integrating affective culture with other elements of an organization's culture and by presenting ideographic accounts that reveal how participants in change believe the affective aspects of organizational culture shaped their emotional reactions. Dramatic changes faced by organizations in the economic crisis, developing in late 2008 and mushrooming in 2009, have strained and altered organizational cultures and put an emotional burden on staff. The lessons from our research study should be of benefit to managers struggling to maintain, adjust or blend organizational cultures and deal with the emotional outcomes for staff.

\section{References}

Alker, M. and McHugh, D. (2000) Human resource maintenance? Organizational rationales for the introduction of employee assistance programmes, Journal of Managerial Psychology, 15(4), pp. 303-323.

Allen, D.K. (2003) Organizational climate and strategic change in higher education: organizational insecurity, Higher Education, 46(1), pp. 61-92.

Alvesson, M. (2002) Understanding Organizational Culture (London: Sage Publications).

Amos, E.A. and Weathington, B. L. (2008) An analysis of the relation between employeeorganization value congruence and employee attitudes, The Journal of Psychology, 142(6), pp. 615-631.

Antonacopoulou, E.P. and Gabriel, Y. (2001) Emotion, learning and organizational change: towards an integration of psychoanalytic and other perspectives, Journal of Organizational Change Management, 14(5), pp. 435-451.

Armenakis, A.A., Harris, S.G. and Mossholder, K.W. (1993) Creating readiness for organizational change, Human Relations, 46(6), pp. 681-703.

Ashforth, B. E. \& Mael, F. (1989) Social Identity Theory and the organization, Academy of Management Review, 14(1), pp. 20-39. 
Ashkanasy, N.M. and Daus, C.S. (2002) Emotion in the workplace: the new challenge for managers, Academy of Management Executive, 16(1), pp. 76-86.

Barclay, L.J., Skarlicki, D.P. and Pugh, D.P. (2005) Exploring the role of emotions in injustice perceptions and retaliation, Journal of Applied Psychology, 90(4), pp. 629643.

Barsade, S.G. and Gibson, D.E. (2007) Why does affect matter in organizations? Academy of Management Perspectives, 21(1), pp. 36-59.

Bean, C.J. and Hamilton, F.E. (2006) Leader framing and follower sensemaking: response to downsizing in the brave new workplace, Human Relations, 59(3), pp. 321-349.

Beugré, C.D. and Baron, R.A. (2001) Perceptions of systemic justice: the effects of distributive, procedural and interactional justice, Journal of Applied Psychology, 31(2), pp. 324-339.

Beyer, J. and Nino, D. (2001) Culture as a source, expression and reinforcer of emotions in organizations, in: R. Payne and C. Cooper (eds), Emotions at Work: Theory, Research and Applications for Management, pp. 173-197 (Chichester, UK: John Wiley and Sons).

Bolton, S. (2005) Emotion Management in the Workplace (Houndsmill, Hampshire: Palgrave Macmillan).

Branson, C.M. (2007) Achieving organizational change through values alignment, Journal of Educational Administration, 46(3), pp. 376-395.

Bratton, J., Grint, K. and Nelson, D.L. (2005) Organizational Leadership (Mason, OH: Thomson South-Western).

Brooks, I. and Harfield, T. (2000) Breaking the psychological contract: the effects of change work on middle managers when implementing organizational change, Asia Pacific Journal of Human Resources, 38(3), pp. 91-103. 
Bryant, M. and Wolfram Cox, J. (2006) Loss and emotional labour in narratives of organizational change, Journal of Management and Organization, 12(2), pp. 116-130.

Callahan, J.L. (2002) Masking the need for cutural change: the effects of emotional structuration, Organization Studies, 23(2), pp. 282-297.

Callahan, J.L. and McCollum, E.E. (2002) Conceptualizations of emotion research in organizational contexts, Advances in Developing Human Resources, 4(1), pp. 4-21.

Carr, A. (1999) The psychodynamics of organisation change: identity and the "reading" of emotion and emotionality in a process of change, Journal of Managerial Psychology, 14(7/8), pp. 573-585.

Ciarrochi, J. and Mayer, J.D. (eds.) (2007) Applying Emotional Intelligence: A Practitioner's Guide (New York: Psychology Press).

Clarke, N. (2006) Developing emotional intelligence through workplace learning: findings from a case study in healthcare, Human Resource Development International, 9(4), pp. 447-465.

Colquitt, J.A. (2001) On the dimensionality of organizational justice: a construct validation of a measure, Journal of Applied Psychology, 86(3), pp. 386-400.

Currie, P. and Dollery, B. (2006) Organizational commitment and perceived organizational support in the NSW police, Policing, 29(4), pp. 741-756.

Denison, D.R. (1996) What is the difference between organizational culture and organizational climate? A native's point of view on a decade of paradigm wars, Academy of Management Review, 21(3), pp. 619-654.

Dent, E. and Goldberg, S. (1999) Challenging resistance to change, Journal of Applied Behavioural Science, 35(1), pp. 25-41.

Disney Corporation (2008) Available at http://corporate.disney.go.com/careers/culture.html.

Domagalski, T.A. (1999) Emotion in organizations, Human Relations, 52(6), pp. 833-852. 
Druskat, V.U. and Pescosolido, A.T. (2006) The impact of emergent leader's emotionally competent behaviour on team trust, communication, engagement and effectiveness, in: W.J. Zerbe, N.M. Ashkanasy and C.E.J. Härtel (eds), Research on Emotions in Organizations, Volume 2: Individual and Organizational Perspectives on Emotion Management and Display, pp. 25-56 (Oxford: Elsevier).

Druskat, V.U. and Wolff, S.B. (2001) Building the emotional intelligence of groups, Harvard Business Review, 79(3), pp. 81-90.

Duck, J.D. (1993) Managing change: The art of balancing, Harvard Business Review, 71(6), pp. 109-118.

Eisenberger, R., Huntington, R., Hutchison, S. and Sowa, D. (1986) Perceived organizational support, Journal of Applied Psychology, 71(3), pp. 500-507.

Elsmore, P. (2001) Organizational Culture: Organizational Change? (Aldershot, Hampshire: Ashgate).

Fineman, S. (2000) Commodifying the emotionally intelligent, in: S. Fineman (ed), Emotion in Organizations, 2nd edn, pp. 101-114 (London: Sage Publications).

Finenan, S. (2001) Emotions and organizational control, in: R. Payne \& C. Cooper (eds), Emotions at Work: Theory, Research and Applications, pp. 219-237 (Chichester, UK: John Wiley \& Sons).

Fineman, S. (2003) Understanding Emotion at Work (London: Sage Publications).

Fineman, S. (2005) Appreciating emotion at work: paradigm tensions, International Journal of Work Organization and Emotion, 1(1), pp. 4-19.

Fineman, S. (2008) Introducing the emotional organization, in: S. Fineman (ed), The Emotional Organization: Passions and Power, pp. 1-11 (Oxford: Blackwell).

Ford, J.D., Ford, L.W. and McNamara, R.T. (2002) Resistance and the background conversations of change, Journal of Organizational Change Management, 15(2), pp. 
105-121.

Forster, N. (2006) Hewlett-Packard - the new way? The Management Case Study Journal, 6(1), pp. 33-52.

Frost, P.J. (2004) Handling toxic emotions: new challenges for leaders and their organizations, Organizational Dynamics, 33(2), pp. 111-127.

Fournier, V. (1999) The appeal to 'professionalism' as a disciplinary mechanism, The Sociological Review, 47(2), 280-307.

Fox, S. and Amichai-Hamburger, Y. (2001) The power of emotional appeals in promoting organizational change programs, Academy of Management Executive, 15(4), pp. 8493.

Frijda, N.H. (1988) The laws of emotion, American Psychologist, 43(5), pp. 349-358.

Goodman, S.A. and Svyantek, D.J. (1999) Person-organization fit and contextual performance: do shared values matter?, Journal of Vocational Behavior, 55(2) 254275.

Guy, M.E. and Newman, M.A. (2004) Women's jobs, men’s jobs: sex segregation and emotional labor, Public Administration Review, 64(3), pp. 289-298.

Haman, M. and Putnam, L.L. (2008) In the gym: pressure and emotional management among co-workers, in: S. Fineman (ed), The Emotional Organization: Passions and Power, pp. 1-73 (Oxford: Blackwell).

Harlos, K.P. and Pinder, C.C. (2000) Emotion and injustice in the workplace, in: S. Fineman (ed), Emotions in Organizations, Volume 2, pp. 1-24 (London: Sage Publications).

Harris, L.C. and Ogbonna, E. (1998) Employee responses to culture change efforts, Human Resources Management Journal, 8(2), pp. 78-92.

Herscovitch, L. and Meyer, J.P. (2002) Commitment to organizational change: Extension of a three-component model, Journal of Applied Psychology, 87(3), pp. 474-487. 
Hochschild, A.R. (1983) The Managed Heart (Los Angeles: University of California Press).

Holt, D.T., Armenakis, A.A., Feild, H.S. and Harris, S.G. (2007) Readiness for organizational change: the systematic development of a scale, The Journal of Applied Behavioral Science, 43(2), pp. 232-255.

Huy, Q.N. (1999) Emotional capability, emotional intelligence and radical change, Academy of Management Review, 24(2), pp. 325-345.

Huy, Q.N. (2001) Time, temporal capability and planned change, Academy of Management Review, 26(4), pp. 601-623.

Isen, A.E. (2000) Positive affect and decision making, in: M. Lewis and J.M. Haviland-Jones (eds), Handbook of emotions, 2nd edn, pp. 417-435 (New York: The Guildford Press).

Jordan, P. (2005) Dealing with organizational change: can emotional intelligence enhance organizational learning?, International Journal of Organizational Behaviour, 8(1), pp. 456-471.

Jordan, P.J., Ashkanasy, N.M., Härtel, C.E.J. and Hooper, G.S. (2002) Workgroup emotional intelligence: scale development and relationship to team process effectiveness and goal focus, Human Resource Management Review, 12(2), pp. 195-214.

Kabanoff, B., Waldersee, R. and Cohen, M. (1995) Espoused values and organizational change themes, Academy of Management Journal, 38(4), pp. 1075-1104.

Kavanagh, M.H. and Ashkanasy, N.M. (2006) The impact of leadership and change management strategy on organizational culture and individual acceptance of change during a merger, British Journal of Management, 17, pp. 81-103.

Keown, J. (2006, 4 November) Voda-fun - the serious business of being crazy, New Zealand Herald, p. C4.

Kiefer, T. (2005) Feeling bad: antecedents and consequences of negative emotions in ongoing change, Journal of Organizational Behavior, 26(8), pp. 875-897. 
Kirkland, R. (2007, 12 November) Cisco’s display of strength, Fortune, pp. 34-44.

Kotter, J.A. \& Schlesinger, L.A. (1979) Choosing strategies for change, Harvard Business Review, 57(2), pp. 106-114.

Kunda, G. and van Maanen, J. (1999) Changing scripts at work: managers and professionals, The Annals of the American Academy, 561, pp. 64-80.

Lazarus, R.S. (1991) Cognition and motivation in emotion, American Psychologist, 46(4), pp. 352-367.

Lewis, K.M. (2000) When leaders display emotion: how followers respond to negative emotional expression of male and female leaders, Journal of Organizational Behavior, 21(2), pp. 221-234.

Lines, R. (2004) Influence of participation in strategic change: resistance, organizational commitment and change goal achievement, Journal of Change Management, 4(3), pp. 193-215.

Lively, K.J. (2000) Reciprocal emotion management: working together to maintain stratification in private law firms, Work and Occupations, 27(1), pp. 32-63.

Loi, R., Hang-yue, N. and Foley, S. (2006) Linking employees' justice perceptions to organizational commitment and intention to leave: the mediating role of perceived organizational support, Journal of Occupational and Organizational Psychology, 79(1), pp. 101-120.

Mann, S. (1999) Hiding what we Feel, Faking what we Don't (Shaftesbury, UK: Element Books).

Martin, J. (2002) Organizational Culture: Mapping the Terrain (Thousand Oaks, CA: Sage Publications).

Martin, J., Knopoff, K. and Beckman, C. (1998) An alternative to bureaucratic impersonality and bounded emotionality at The Body Shop, Administrative Science Quarterly, 4(2), 
pp. 429-469.

Masterson, S.S., Lewis, K., Goldman, B.M. and Taylor, M.S. (2000) Integrating justice and social exchange: the differing effects of fair procedures and treatment on work relationships, Academy of Management Journal, 43(4), pp. 738-748.

Mayer, J.D. and Salovey, P. (1997) What is emotional intelligence? In: P. Salovey and D.J. Sluyter (eds.), Emotional Development and Emotional Intelligence: Educational Implications, pp. 3-31 (New York: Basic Books).

McEnrue, M.P., Groves, K. S. and Shen, W. (2009) Emotional intelligence development: leveraging individual characteristics, The Journal of Management Development, 28(2), pp. 150-174.

Menges, J.I. and Bruch, H. (2009) Organizational emotional intelligence: an empirical study, in: C.E.J. Hartel, N.M. Ashkanasy and W.J. Zerbe (eds), Research on Emotion in Organizations, Vol. 5, Emotions in Groups, Organizations and Cultures, pp. 181-209 (Bingley, UK: Emerald Group Publishing).

Mills, C.E. (2000) The interfaces of communication, sensemaking, and change, Australian Journal of Communication, 27(1), pp. 95-110.

Morgan, P.I. and Ogbonna, E. (2008) Sub-cultural dynamics in transformation: a multiperspective study of healthcare professionals, Human Relations, 6(1), pp. 39-65

Naumann, S.E., Bennett, N., Bies, R.J. and Martin, C.L. (1998) Laid off but still loyal: the influence of perceived justice and organizational support, International Journal of Conflict Management, 9(4), pp. 356-368.

Palthe, J. and Kossek, E. L. (2003) Subcultures and employment modes: translating HR strategy into practice, Journal of Organizational Change Management, 16(3), pp. 287308.

Payne, R.L. (2002), Culture and climate: how close can they get?, in: N.M. Ashkanasy, C.P. 
M. Wilderom and M.F. Peterson (eds), Handbook of Organizational Culture and Climate, pp. 163-176 (Thousand Oaks, CA: Sage Publications).

Pepper, G.L. and Larson, G.S. (2006) Cultural identity tensions in a post-acquisition organization, Journal of Applied Communication Research, 34(1), pp. 49-71.

Piderit, S. K. (2000) Rethinking resistance and recognizing ambivalence: a multi-dimensional view of attitudes towards organizational change, Academy of Management Review, 25(4), pp. 783-794.

Pizer, M.K. and Härtel, C.E.J. (2005) For better or for worse: organizational culture and emotions, in C.E.J. Härtel, W.F. Zerbe and N.M. Ashkanasy (eds), Emotions in Organizational Behaviour, pp. 335-354 (Mahwah, NJ: Lawrence Erlbaum Associates).

Putnam, D.K. \& Mumby, L.L. (1992) The politics of emotions: a feminist reading of bounded rationality, Academy of Management Review, 17(3), 465-486.

Rafaeli, A. and Sutton, R.I. (1990) Busy stores and demanding customers: how do they affect the display of positive emotion?, Academy of Management Journal, 3(3), pp. 623-637.

Roberts, L.A. (2005) Changing faces: professional image construction in diverse organizational settings, Academy of Management Review, 30(4), pp. 685-711.

Rosen, M. (1991) Coming to terms with the field: understanding and doing organizational ethnography, Journal of Management Studies, 28(1), pp. 1-24.

Rudisill, J.R. and Edwards, J.M. (2002) Coping with job transitions, Consulting Psychology Journal: Practice and Research, 54(1), pp. 55-64.

Ryan, B. (2005) The problematic nature of organizational culture and a changing control context, Strategic Change, 14(8), pp. 431-440.

Schein, E. (1990) Organizational culture, American Psychologist, 45(2), pp. 109-119.

Schein, E. (2004) Organizational Culture and Leadership (San Francisco: Jossey-Bass). 
Schwandt, T.A. (1998) Constructivist and interpretivist approaches to human inquiry, in: N.K. Denzin and Y.S. Lincoln (eds), The Landscape of Qualitative Research: Theories and issues, 1st edn, pp. 221-259 (Thousand Oaks, CA: Sage Publications).

Schwandt, T.A. (2003) Three epistemological stances for qualitative enquiry: interpretivism, hermeneutics and social constructionism, in: N.K. Denzin and Y.S. Lincoln (eds), The Landscape of Qualitative Research: Theories and Issues, 2nd edn, pp. 292-33 (Thousand Oaks, CA: Sage Publications).

Self, D.R., Armenakis, A.A. and Schraeder, M. (2007) Organizational change content, process, and context: a simultaneous analysis of employee reactions, Journal of Change Management, 7(2), pp. 211-229.

Sheppard, B.H., Lewicki, R.J. and Minton, J.W. (1992) Organizational Justice: The Search for Fairness in the Workplace (New York: Lexington Books).

Smollan, R.K. (2006) Minds, hearts and deeds: cognitive, affective and behavioural responses to change, Journal of Change Management, 6(2), 143-158.

Strandgard Pedersen, J. and Dobbin, F. (2006) In search of identity and legitimation: bridging organizational culture and neoinstitutionalism, The American Behavioral Scientist 49(7), pp. 897-907.

Sturdy, A. and Fineman, S. (2001) Struggles for the control of affect: resistance as politics and emotion, in: A. Sturdy, I. Grugulis and H. Willmott (eds), Customer Service; Empowerment and Entrapment, pp. 135-156 (Basingstoke, Hampshire: Palgrave).

Szabla, D. (2007) A multidimensional view of resistance to organizational change: Exploring cognitive, emotional, and intentional responses to planned change across perceived change leadership strategies, Human Resource Development Quarterly, 18(4), pp. 525-558.

Tse, H.M., Dasborough, M.T and Ashkanasy, N.M. (2008) A multi-level analysis of team 
climate and interpersonal exchange relationships at work, The Leadership Quarterly, 19(2), pp. 195-211.

Turnbull, S. (1999) Emotional labour in corporate change programmes: the effect of organizational feeling rules on middle managers, Human Resources Development International, 2(2), pp. 125-146.

Turnbull, S. (2002) The planned and unintended emotions generated by a corporate change program, Advances in Developing Human Resources, 4(1), pp. 22-38.

Vandenberghe, C. (1999) Organizational culture, person-culture fit, and turnover: a replication in the health care industry, Journal of Organizational Behavior, 20(2), pp. 175-184.

Van Dijk, R.L. and van Dick, R. (2009) Navigating organizational change: change leaders, employee resistance and work-based identities, Journal of Change Management, 9(2), pp. 143-163.

Van Knippenberg, D., van Knippenberg, B., Monden, L. and de Lima, F. (2009) Organizational identification after a merger, British Journal of Social Psychology, 41(1), 233-252.

Van Maanen, J. and Kunda, G. (1989) "Real feelings": emotional expression and organizational culture, Research in Organizational Behaviour, 2, pp. 43-103.

Virgin (2008) Available at http://www.virgin.com/RBP/People.aspx.

Vodafone New Zealand (2008) Available at www.vodafone.co.nz/personal/about/companyinformation/ people-and-culture/vision-values.jsp.

Wanberg, C.R. and Banas, J.T. (2000) Predictors and outcomes of openness to changes in a reorganizing workplace, Journal of Applied Psychology, 85(1), pp. 132-142.

Weiss, H. M. (2002) Conceptual and empirical foundations for the study of affect at work, in: R.G. Lord, R.J. Klimoski and R. Kanfer (eds), Emotions in the Workplace: 
Understanding the Structure and Roles of Emotions in Organizational Behavior, pp. 20-63 (San Francisco: Jossey-Bass).

Zembylas, M. (2006) Challenges and possibilities in a postmodern culture of emotions in education, Interchange, 37(3), pp. 251-275. 